\title{
Beta-thalassemia associated with another hemoglobin anomaly
}

INSERM

\section{Source}

INSERM. (1999). Orphanet: an online rare disease and orphan drug data base. Betathalassemia associated with another hemoglobin anomaly. ORPHA:231230

Beta-thalassemias associated with hemoglobin $(\mathrm{Hb})$ anomalies result in a variable clinical spectrum, rang ing from asymptomatic to severe, depending on the severity of the thalassemia mutation and on the type of the $\mathrm{Hb}$ anomaly [hereditary persistence of fetal $\mathrm{Hb}$, delta-beta-thalassemia, $\mathrm{Hb} \mathrm{C}$ - beta-thalassemia, $\mathrm{Hb}$ - beta-thalassemia and $\mathrm{Hb} \mathrm{S}$ beta-thalassemia (see these terms)]. 